"THE choice before mankind is a very simple one: nuclear disarmament or oblivion. In the absence of disarmament, more and more nuclear weapon powers will emerge. A limited nuclear war will eventually break out which may well escalate to a strategic nuclear exchange between the superpowers and extinguish our civilisation. The nuclear paradox is Man's total inability to cope with the obvious, even when it is a matter of life and death for the human race." With these words Dr Frank Barnaby, Director of the Stockholm International Peace Research Institute (SIPRI), justified the pessimistic outlook of the Institute's Yearbook 1974 recently published in Stockholm. Like its four predecessors, this yearbook is about armaments and disarmament. After surveying the state of the armed world and the developments affecting it during 1973, the institute restates its commitment to general and complete disarmament as the only possibility for survival.

SIPRI readers have by now learned to expect the authoritative and sobering picture which emerges from this yearbook as from the institute's many other publications. It comes as no surprise to read that "... by the end of 1973 there was still little evidence that the degree of disorder in international affairs was decreasing". The bright spots of the year fall into place as acts of political necessity which have done nothing to stop the proliferation of conventional weapons or the continuing pressures towards technological refinement of both conventional and nuclear arms.

In 1973 the world spent $\$ 207,000$ million on arms, of which $\$ 20,000$ million was for military research and development. Since 1968 world military expenditure has been constant at about this level; therefore the latest figure represents a slightly lower proportion of world GNP now than it did then.

\section{SIPRI pulls it all together}

The unchanged figure however, disguises a disturbing trend: "The share of world military expenditure absorbed by the United States, the Soviet Union, France and the United Kingdom, taken together, has declined from $82 \%$ in 1955 to $70 \%$ in 1973 . This does not reflect a reduction in the military capability of these four countries but rather indicates the magnitude of the increase in militarisation elsewhere." India's recent nuclear explosion illustrates this only too well.

The peculiar value of the SIPRI year books is that they relate all the happenings of a year, putting the events hailed as political milestones in perspective beside continuing world trends. Amidst the triumphant conclusion of the Israeli-Syrian disengagement agreement and the optimistic forecasts of its effect on future oil deliveries, for example, it is easy to overlook what is happening in other parts of the Middle East. The Persian Gulf is a critically important area for the shipment of oil. In recent years, the countries bordering the Gulf have, according to the yearbook, dramatically increased their military expenditures. Iran and Saudi Arabia have led the way. Over the decade 1963-1973 the average annual rate of increase of military expenditure in these countries was $23 \%$. During 1973, Iran had outstanding orders for about 800 Chieftain main battle tanks, 250 Scorpion light tanks, more than 200 F-4E/F-5E fighter aircraft and nearly 500 helicopters, including about 200 Sea Cobra gunships armed with the latest US anti-tank missiles. The prospect of the Gulf countries being armed to the teeth and about to wield such influence over oil shipments may well make us rethink the current relief over developments in another part of the Middle East.

Current nuclear events make the yearbook's discussion of nuclear policies particularly interesting. The statement on January 10 by the United States Secretary of Defense that the United States would in future pursue a counterforce strategy is interpreted by SIPRI as a justification for continuing the development of weapons for whose future deployment the doctrine of 'mutual assured destruction' provided no rationale. Of particular concern is the fact that enormous resources are being devoted to antisubmarine warfare technology, which is already sufficiently advanced to allow the destruction of a portion of the enemy's strategic nuclear submarine force. On the tactical level, it has been suggested that accurately delivered low yield nuclear weapons should replace the higher yield nuclear weapons now deployed, particularly in Europe. SIPRI objects to this proposal because "it is of paramount importance that an absolute 'firebreak' should be maintained between nuclear and conventional war".

It is surprising that SIPRI emphasises its basic commitment to effective disarmament as the only sure way of lessening threats all over the world, in spite of the facts that the yearbook is aimed largely at governments and that the institute is well aware that 'disarmament' is a dirty word in many government circles. The official intolerance of disarmament detracts from the practical value of the Yearbook's solution, for history shows that political will is essential for negotiated progress in any direction. In going against the stream, SIPRI is not merely being politically naive. It is attesting to the fact that it sees no middle way between disarmament and annihilation.
THE US House of Representatives voted last week to kill the Large Space Telescope (LST)-one of the most important astronomy programmes being planned for the $1980 \mathrm{~s}$ - by deleting funding for the project from NASA's budget. If the Senate follows suit. NASA will have to revamp the project and come up with a cheaper option, but according to congressional sources, it is likely that the Senate Appropriations Committe will restore at least some of the money to keep LST alive.

NASA had asked for some $\$ 6.2$ million for the 1974-75 fiscal year for planning and design of the I.ST, before moving into the development phase. But the Appropriations Committee recommended that the money should

\section{LST in danger}

be denied this year and that "A less expensive and less ambitious project be considered as an alternative." The recommendation was approved by the House itself last week when it voted on NASA's budget.

A 120-inch optical telescope, the LST would be about 100 times more powerful than the largest ground-based instruments now in operation. It would be launched in the early 1980s-probably in 1981-by the space shuttle and it would be periodically serviced and upgraded during its 15-year lifetime. It has been enthusiastically endorsed by the Space Science Board of the
National Academy of Sciences but the House Appropriations Committee was evidently concerned at the large estimated costs of the project-between $\$ 200$ and 300 million.

Now that it has been approved by the House, NASA's budget must be considered by the Senate. The Senate Appropriations Committee is likely to report out a bill later this month and if the full Senate does eventually restore funding for the LST, the matter would have to be resolved by a HouseSenate conference committee. Congressional sources predicted that the funds would be approved by the Senate and agreed to by the conference committee, but the outcome at this stage is far from certain. 